\title{
IPTEK BAGI WILAYAH KECAMATAN LEBONG TENGAH KABUPATEN LEBONG
}

\section{IPTEK FOR REGION OF LEBONG TENGAH SUBDISTRICT LEBONG DISTRICT}

\author{
Oleh: \\ Reswita $^{1}$, Satria Putra Utama ${ }^{1}$, Kurnia Herlina Dewi ${ }^{2}$, dan Yulfiperius ${ }^{3}$ \\ ${ }^{1}$ Jurusan Sosial Ekonomi Pertanian Fakultas Pertanian Universitas Bengkulu \\ ${ }^{2}$ Jurusan Teknologi Industri Pertanian Universitas Bengkulu \\ ${ }^{3}$ Jurusan Budidaya Perikanan Fakultas Pertanian Universitas Hazairin \\ reswita17@yahoo.co.id
}

\begin{abstract}
Central Lebong Sub District is one district that has significant potential in the district Lebong. The biggest potential is in agriculture, including food crops, plantations and fisheries. Although it has great potential, but there are still many problems faced by the region administration in the District Lebong Lebong Central. The programs that have been implemented as a solution for dealing with problems in the target areas IBW III is 1) Procurement of equipment to support the manufacture of palm sugar ants and entrepreneurial activity, 2) Increased production of palm sugar ants, 3) Trained making of coffee powder, 4) trained making palm civet coffee, 5) trained making of ginger coffee, 6) Increased production of coffee Brown Sugar, 7) Improved the economic of women through entrepreneurship training, 8) Promotional products through direct sales and exhibition, 9) Home gardens for garden plants, inland fisheries, and livestock in an integrated way, 10) Environmental health education and the availability of clean water, 11) Trained the manufacture of fish feed for the farmer groups, 12) Provided assistance toilet facilities.
\end{abstract}

Keywords: palm sugar, products diversification, refined palm sugar, IbW palm coffee

\section{PENDAHULUAN}

Kabupaten Lebong merupakan salah satu kabupaten di provinsi Bengkulu yang beribukota Muara Aman. Kabupaten ini terletak di posisi $105^{\circ}-108^{\circ}$ Bujur Timur dan $02^{\circ}, 65^{\prime}-03^{\circ}, 60^{\prime}$ Lintang Selatan di sepanjang Bukit Barisan serta terklasifikasi sebagai daerah Bukit Range pada ketinggian 500-1.000 dpl. Secara adminstratif, Kabupaten Lebong berbatasan langsung dengan Sebelah Utara berbatasan dengan Provinsi Jambi, Sebelah Timur berbatasan dengan Provinsi Sumatera Selatan, Sebelah Selatan berbatasan dengan Kabupaten Rejang Lebong dan Bengkulu Utara, dan Sebelah Barat berbatasan dengan Kabupaten Bengkulu Utara. Luas wilayah Kabupaten Lebong + 272.924 Ha terdiri dari 13 kecamatan yang meliputi 100 desa dan 11 kelurahan.

Salah satu kecamatan yang memiliki potensi cukup besar di kabupaten Lebong adalah adalah Kecamatan Lebong Tengah. Potensi dibidang pertanian, diantaranya 
pertanian tanaman pangan, perkebunan dan perikanan. Tanaman padi merupakan komoditi unggulan, luas area produksi padi sebesar 26.628 ha, dengan jumlah produksi 57.510 Ton dengan produksi 2,2 Ton/ha. Selain padi, komoditi tanaman strategis lainnya seperti Jagung dengan luas 1.422 ha, dengan jumlah produksi Jagung 4.785 Ton dengan produksi 3,4 Ton/ha. Produksi Kedelai 40 ha, dengan jumlah Kedelai 0,7 Ton/ha. Terdapat juga beberapa Tanaman Palawija seperti Kacang Tanah 72 ha (1 ton/ha), Kacang Hijau 28 ha (9,3 ton/ha), Ubi Kayu 94 ha (11,6 ton/ha) dan Ubi Jalar 76 ha (9,54 ton/ha). Di sektor perkebunan yang komoditi unggulan kopi robusta yang masih di dominasi oleh perkebunan rakyat, aren, dan jahe. Potensi sumber daya perikanan yang dikembang di adalah kolam air deras, keramba jaring apung, dan sawah (mina padi) di lahan persawahan. Subsector peternakan didominasi oleh ternak kambing, itik, dan ternak ayam.

Meskipun memiliki potensi yang cukup besar, namun masih banyak persoalanpersoalan yang dihadapi oleh pemerintahan Kabupaten Lebong. Persoalan yang dihadapi Pemda di Kacamatan Lebong Tengah ini, yang merupakan wilayah IbW diantaranya : 1. Persoalan Pertanian dan Ketahanan Pangan, Perkebunan, dan Perikanan, seperti 1) Belum optimalnya pemanfaatan lahan untuk pengembangan pertanian, perkebunan, dan perikanan, ini terlihat dari banyak lahan tidur yang tidak dimanfaatkan, 2) Produktivitas dan nilai tambah sektor pertanian, perkebunan dan perikanan masih cukup rendah, 3) Penggunaan teknologi (mekanisasi) pertanian masih belum optimal, 4) Terminal agribisnis dan penggunaan Saprodi pertanian belum berfungsi secara optimal, 5) Masih rendahnya teknologi, sarana dan prasarana perikanan, 6)Kurangnya modal kerja dan belum profesionalnya manajemen pengelolaan perikanan darat. 2. Persoalan Bidang koperasi dan usaha kecil dan menengah, indusrti, dan perdagangan. Permasalahan utama yang menjadi kendala di bidang perindusrtian, perdagangan, koperasi dan UKM adalah :1) Sarana dan prasarana di bidang industri masih kurang, serta rendahnya pertumbuhan industri kecil dan menengah, 2) Masih kurangnya pengetahuan SDM masyarakat di sektor industri, 3) Belum dikelolanya koperasi dengan optimal dan kurangnya penggalian potensi bidang perkoperasian dan UKM, 4) Keterbatasan pengetahuan, informasi dan ketrampilan terkait proses produksi yang benar, hygienis dan memenuhi standar mutu olahan pangan, 6) Keterbatasan sarana prasarana produksi sehingga produktivitas masih rendah. 3. Persoalan Bidang Kesehatan, diantaranya: 1) Masih rendahnya kesadaran masyarakat dalam pengembangan lingkungan sehat, 2) Masih lemahnya pengawasan dan pengendalian keamanan kesehatan makanan hasil produksi rumahan, 3) Sarana dan akses pelayanan kesehatan belum optimal

Solusi yang ditawarkan adalah: 1) Pemanfaatan lahan perkarangan untuk pengembangan dan penanaman tanaman pangan dan perkebunan yang menunjang untuk pengembangan agroindustri tanaman pangan, agroindustri tanaman perkebunan, dan untuk memenuhi kebutuhan pengembangan industry pakan ternak unggas dan ikan, dan pengembangan usaha perikanan budidaya, 2) Meningkatkan produksi dengan mengoptimalkan penggunaan faktor-faktor produksi penunjang tanaman pangan, 
perkebunan, dan perikanan, 3) Untuk meningkatkan nilai tambah perlu dilakukan diversifikasi usaha dengan memanfaatkan potensi yang ada, 4) Untuk mengembangkan kreativitas untuk memiliki jiwa wirausaha perlu dilakukan pelatihan-pelatihan kewirausahaan yang memanfaatkan potensi yang ada, 5) Pengembangan pasar dan distribusi produk, 6) Peningkatan kesehatan masyarakat, 7) Meningkatkan perbaikan gizi masyarakat melalui pelatihan teknologi pengolahan pangan, 8) Meningkatkan nilai tambah produk perikanan melalui pelatihan teknologi pengolahan, dan 9) Meningkatkan produksi hasil perikanan melalui pelatihan pembuatan pakan ikan.

Program-program yang akan dilaksanakan sebagai solusi untuk menangani permasalah wilayah sasaran IBW pada tahun III adalah 1) Pengadaan peralatan penunjang pembuatan gula semut dan kegiatan kewirausahaan, 2) Peningkatan produksi gula semut, 3) Pelatihan pembuatan kopi bubuk, 4) Pelatihan pembuatan kopi luwak aren, 5) Pelatihan Pembuatan kopi jahe, 6) Pembuatan Kopi Gula aren lanjutan, 7) Peningkatan Ekonomi perempuan melalui pelatihan kewirausahaan, 8) Promosi produk melalui penjualan langsung dan pameran, 9) Pemanfaatan perkarangan rumah untuk tanaman perkarangan, perikanan darat, dan ternak secara terintegrasi, 10) Penyuluhan kesehatan lingkungan dan ketersediaan air bersih, 11) Pelatihan pembuatan pakan ikan bagi kelompok tani, 12) Pemberian bantuan sarana MCK.

\section{METODE PENGABDIAN}

Metode pelaksanaan kegiatan yang diterapkan dalam upaya untuk mencapai tujuan program adalah metode pemberdayaan masyarakat yang dikenal dengan nama metode PALS (Participatory Action and Learning System) yang dikembangkan oleh Linda Mayouk pada tahun 2000 (Chambers, 2007). Metode PALS ini merupakan salah satu metode yang masuk dalam lingkup metode PLA (Participatory Learning Action) yang merupakan hasil perubahan dari metode RRA (Rapid Rural Appraisal). Beberapa prinsip dasar dari metode PALS ini adalah: 1) menempatkan masyarakat di desa sasaran sebagai objek dan sekaligus sebagai subjek kegiatan, 2) pelaksanaan program menggunakan berbagai pendekatan, 3) pelaksanaan program berfokus pada kebutuhan atau kepentingan masyarakat, 4) program-program memiliki sifat pemecahan masalah, pemberdayaan masyarakat dan pengembangan wilayah, 5) pelaksanaan program bersifat sistemik, dan 6) pelaksanaan program bersifat mencerdaskan dan meransang aktivitas masyarakat. Dalam program IbW ini, masyarakat dilibatkan mulai dari proses perencanaan, proses pelaksanaan hingga proses monitoring dan evaluasi kegiatan. 


\section{HASIL DAN PEMBAHASAN}

\section{Persiapan Kegiatan}

Pelaksanaan kegiatan IbW tahun ketiga dilaksanakan dari bulan April 2016 sampai dengan bulan Oktober 2016. Kegiatan diawali dengan rapat Tim mengenai jadwal dan agenda IbW tahun 2016. Pada tanggal 06 April 2016 dilaksanaan kegiatan koordinasi ke Bappeda Kabupaten Lebong dan sosialisasi ke kelompok sasaran.

\section{Pelaksanaan Kegiatan}

Pengadaan peralatan penunjang pelaksanaan kegiatan $\mathrm{IbW}$

Peralatan Penunjang pelaksanaan kegiatan IBW adalah oven, mesin cetak stik, mesin cup, kukusan, dan mesin cetak label. Ketersediaan peralatan ini sangat diperlukan untuk menunjang keberhasilan kegiatan pelatihan kewirausahaan, dapat menghemat biaya dan dan efeisiensi dalam menyelesaikan pekerjaan. Dengan keberadaan mesin ini diharapkan dapat membantu memperlancar kegiatan kewirausahaan sehingga masyarakat yang dapat dijadikan bekal keterampilan dan pengetahuan kewirausahaan selanjutnya.

\section{Peningkatan produksi dan pengembangan produk gula aren dan kopi bagi pengrajin gula} aren

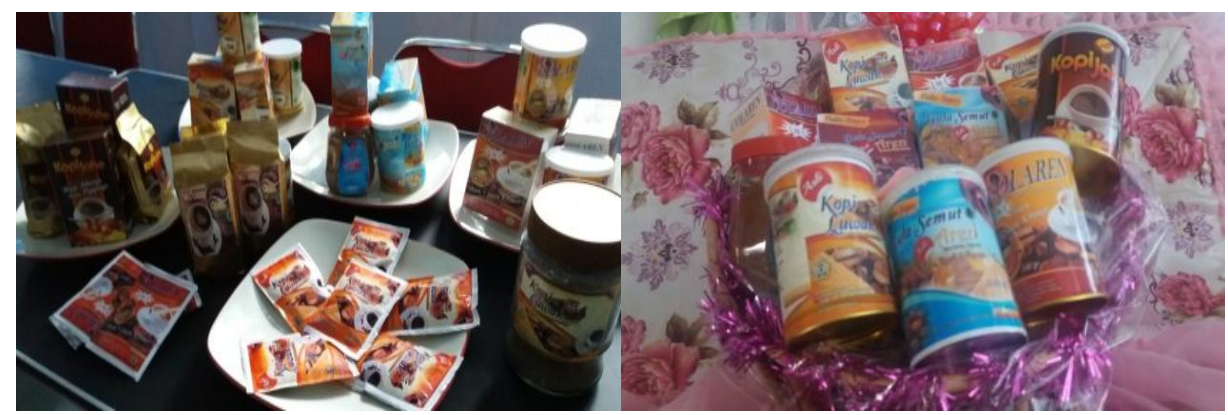

\section{Peningkatan Produksi Gula Semut Aren}

Gula semut yang diproduksi selama ini kapasitasnya masih kecil atau masih sedikit. Tinggi rendahnya produksi ini disebabkan oleh beberapa faktor, diantaranya ketersediaan bahan baku yang tidak kontinyu yang kualitasnya tidak selalu terjamin dan fluktuasi harga bahan baku yang tidak menentu. Gula semut dibuat dari gula aren batok yang dilarutkan kembali kemudian baru diproses menjadi gula semut. Sumber bahan baku berasal dari anggota kelompok. Jumlah produksi dan kualitas gula aren yang dihasilkan oleh anggota sangat dipengaruhi oleh keadaan cuaca. Pada saat musim kemarau jumlah nira cenderung menurun dan rasanya asam dan pada waktu musim penghujan nira tidak bisa dipanen karena kebun-kebun anggota kelompok pengrajin yang jauh diperbukitan. Selain permasalahan ketersediaan bahan baku ditingkat pengrajin rendahnya produktifitas selama ini belum tersedianya mesin pengering gula semut. Apabila cuaca tidak benar-benar panas kegiatan produksi tidak bisa dilakukan. Pada tahun ketiga ini Tim IbW memberikan bantuan oven untuk pengering gula semut. Jumlah produksi yang dihasilkan pada tahun 
ketiga ini sebanyak $100 \mathrm{~kg}$ per bulan dengan harga jual Rp. 35.000 per kg. Apabila dibandingkan dengan harga jual di daerah lain di provinsi Bengkulu yang harganya ratarata Rp. 25.000 per kg dan harga di tingkat pedagang pengumpul gula semut harga Rp. 22.000 per $\mathrm{kg}$, harga jual ini masih tinggi sehingga masih sulit untuk bersaing dan belum bisa dijual ke pedagang pengumpul yang banyak mendistribusikan gula semut ke provinsi Sumatera Selatan dan provinsi Lampung. Untuk keberlanjutan kegiatan produksi gula semut ini di masa yang akan datang perlu adanya penyusunan strategi produksi yang dapat memperkecil biaya produksi, meningkatkan volume dan kualitas gula semut yang dihasilkan dengan cara melakukan pembuatan gula semut langsung berdekatan dengan sentra produksi air nira. Kekuatan yang sudah dimiliki oleh kelompok pengrajin gula semut saat ini adalah sudah memiliki no. PIRT dari Dinkes dan kemasan yang sudah memenuhi standar hasil binaan Tim IbW.
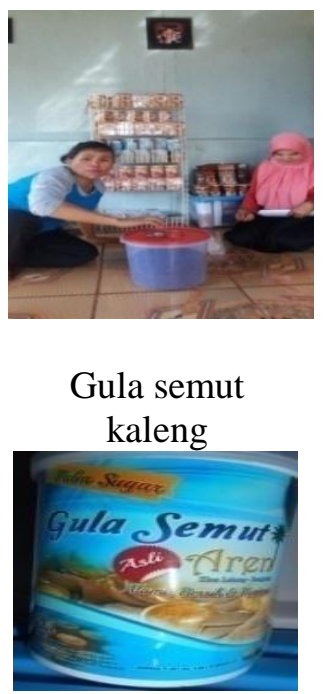

HPP Rp. 14.000

Harga jual

Rp. 20.000

Margin Rp. 6.000
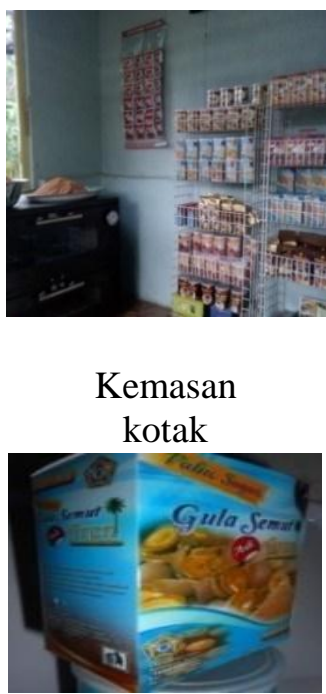

HPP Rp. 18.000

Harga jual

Rp. 25.000

Margin Rp. 7.000

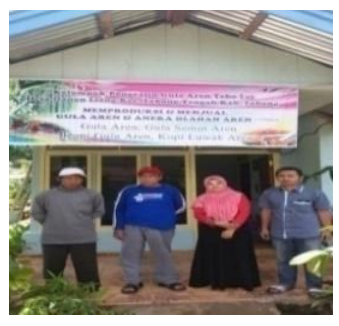

Kemasan botol plastik

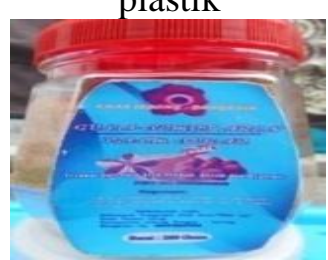

HPP Rp. 10.000

Harga jual

Rp. 15.000

Margin Rp. 5.000

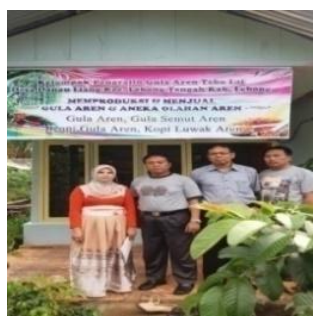

Kemasan alumunium

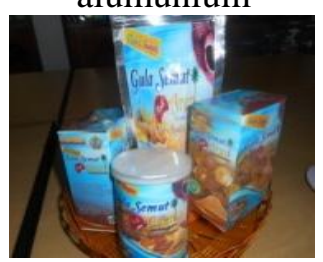

HPP Rp.8.000

Harga jual

Rp. 12.000

Margin Rp. 4.000

\section{Pelatihan Pembuatan Kopi Bubuk}

Hasil perkebunan di kecamatan Lebong Tengah bermacam-macam tidak hanya aren. Kopi Robusta juga merupakan komoditi perkebunan yang memberikan banyak kontribusi bagi penghasilan pengrajin aren dan petani lainnya. Tanaman kopi sebagian ditanam diantara pohon aren dan karet. Penjualan dari kopi umumnya masih dalam bentuk olahan kopi primer, yaitu kopi yang dijemur kering dijual dengan harga Rp. 18.000 per kg sampai dengan Rp. 21.000 per kg. Bila dibandingkan dengan harga kopi yang mereka beli untuk dikonsumsi sangat berbeda jauh sekali, yaitu Rp. 42.000 per kg. Dari penjualan beras kopi nilai tambah yang dirasakan oleh petani kopi bila masih belum signifikan. 
Untuk itu pengolahan kopi menjadi produk bernilai tambah perlu dilakukan sebagai upaya untuk memperbaiki dan meningkatkan penerimaan pengrajin aren dan petani kopi lainnya.

Berbisnis olahan kopi merupakan peluang usaha yang cukup menjanjikan karena tidak terlepas dari kegemaran masyarakat dalam mengkonsumsi kopi karena kopi memiliki rasa, aroma yang khas, dan mempunyai manfaat tersendiri bagi penikmatnya. Keberhasilan bisnis kopi membutuhkan berbagai inovasi dalam pembuatan produk untuk meningkatkan nilai tambah seperti diolah menjadi kopi bubuk, kopi instan, kopi biji matang (roasted coffee), kopi mix, kopi celup, aneka minuman kopi dalam kemasan, dan aneka produk turunan lainnya agar dapat bersaing di pasar produk-produk yang dihasilkan.

Dari hasil pengolahan kopi menjadi kopi bubuk didapat perbandingan antara nilai output yang dihasilkan dengan nilai input yang digunakan dihasilkan nilai faktor konversi, yaitu sebesar 0,75. Nilai konversi ini menunjukkan setiap pengolahan $1 \mathrm{~kg}$ biji kopi dihasilkan kopi bubuk sebanyak $0,75 \mathrm{Kg}$. Nilai out put atau produk kopi bubuk per kg sebesar Rp. 32.250,00. Jadi, nilai tambah yang diperoleh dari hasil pengolahan $1 \mathrm{~kg}$ biji kopi dengan harga bahan baku Rp 20.500,00 untuk menjadi $1 \mathrm{~kg}$ kopi bubuk adalah sebesar Rp 10.346,67/kg. Rasio nilai tambah yang diperoleh adalah 32,08\%. Hal menunjukkan, dalam pengolahan biji kopi menjadi kopi bubuk memberikan nilai tambah sebesar 32,08\% dari nilai produk (Reswita, 2016).

Kopi Bubuk Robusta

Kemasan kaleng foil

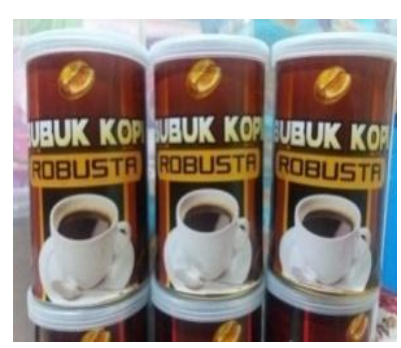

HPP

Rp.13.500.

Harga jual

Rp. 20.000

Margin

Rp. 6.500
Kopi Bubuk Robusta

Kemasan Al. Foil

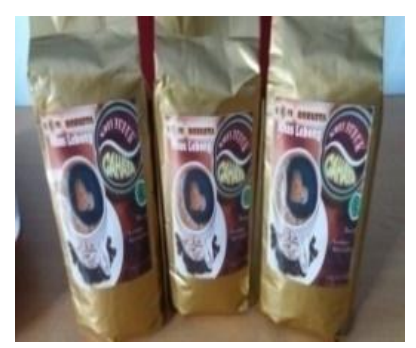

HPP

Rp.8.000

Harga jual

Rp. 15.000

Margin

Rp. 7.000 


\section{Diversifikasi Produk Gula Semut Aren dan Kopi}

Kopi Mix Gula Semut Aren

\section{Produk}

\section{Collaren Mocca}

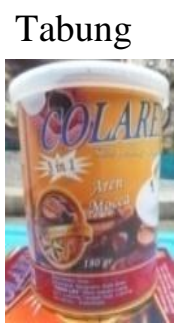

HPP

Rp. 15.500

Harga jual

Rp. 25.000

Margin

Rp. 9.500

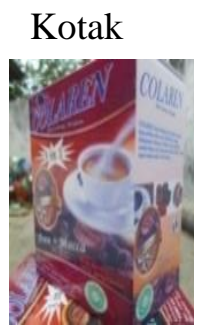

HPP

Rp.20.000

Harga jual

Rp. 30.000

Margin

Rp. 10.000

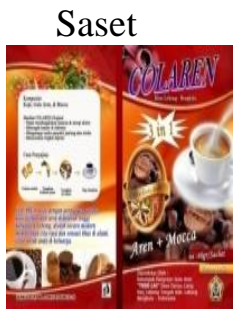

HPP

Rp. 1.500

Harga jual

Rp. 2.000

Margin

Rp. 500

Collaren Original

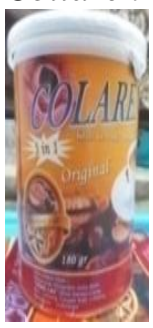

HPP

Rp.15.450

Harga jual

Rp. 25.000

Margin

Rp. 6.500

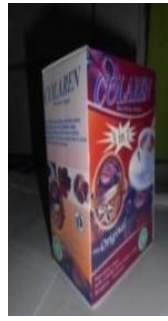

HPP

Rp. 25.000

Harga jual

Rp. 20.000

Margin

Rp. 6.500

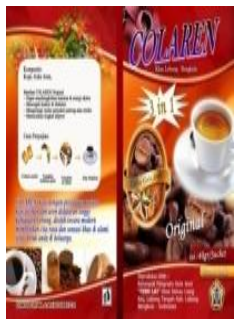

HPP

Rp.1.500

Harga jual

Rp. 20.000

Margin

Rp. 6.500

\section{Collaren Krimer}

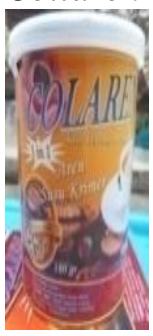

\section{HPP}

Rp. 14.500

Harga jual

Rp. 20.000

Margin

Rp. 6.500

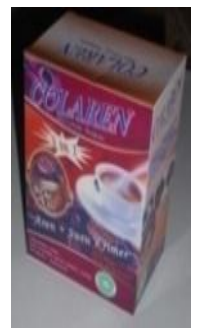

HPP

Rp. 24.500

Harga jual

Rp. 20.000

Margin

Rp. 6.500

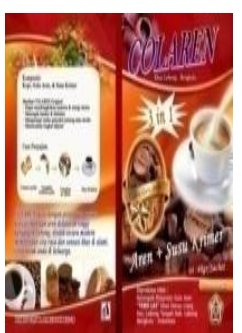

HPP

Rp. 1.500

Harga jual

Rp. 20.000

Margin

Rp. 6.500

\section{Kopi Jahe}

Kopi jahe adalah minuman yang dimodifikasi dari perpaduan bahan kopi robusta dan jahe. Minuman kopi jahe memiliki banyak manfaat, diantaranya, sebagai anti-oksidan yang sangat berguna bagi kesehatan tubuh, sebagai antikoagulan yang bermanfaat untuk mencegah penggumpalan darah yang merupakan penyebab utama dari penyakit stroke dan serangan jantung, pembangkitkan nafsu makan, memperkuat lambung dan usus, serta melancarkan pencernaan, mengobati perut mual, selesma, batuk, diare, dan radang sendi tulang seperti arthritis, membersihkan tubuh melalui keringat. Meskipun pun kelihatan minuman yang sederhana namun kopi jahe memiliki manfaat yang bagus bagi kesehatan. Pembuatan produk kopi jahe sangat didukung oleh ketersediaan baku yang melimpah. 


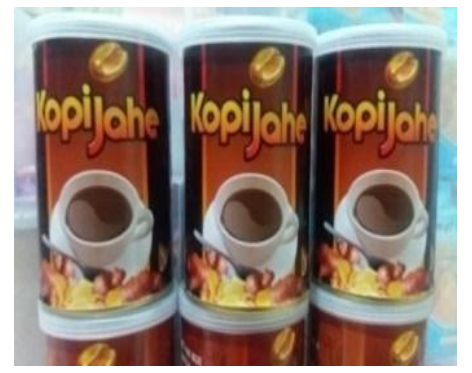

\section{HPP}

Rp. 15.000

Harga jual Rp.

25.000

Margin

Rp. 10.000

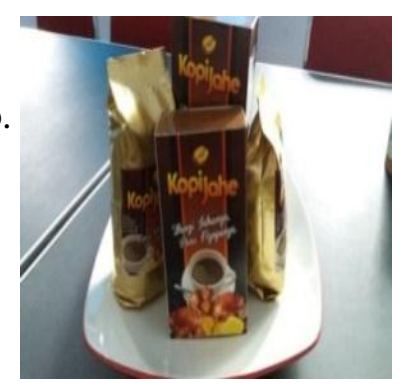

HPP

Rp. 10.000

Harga jual

Rp. 20.000

Margin

Rp. 10.000

\section{Kopi Luwak Gula Semut Aren}

Kopi luwak adalah kopi yang dihasilkan dari biji kopi yang dimakan oleh binatang bernama luwak. Jenis kopi luwak yang diproduksi adalah kopi luwak robusta. Kopi luwak berasal dari luwak liar. Di Kabupaten Lebong Tengah banyak petani kopi yang belum mengetahui bahwa biji kopi luwak harga jual cukup tinggi. Selama ini biji kopi luwak ini dicampur dengan penjualannya dengan kopi biasa. Saat panen kopi jumlah biji kopi luwak yang bisa dikumpulkan petani kopi bisa mencapai $15 \mathrm{~kg}$. Pada saat pelatihan pembuatan kopi luwak aren disosialisasikan bahwa kopi luwak memiliki nilai ekonomis yang cukup tinggi. Penjualan kopi luwak dalam bentuk beras kopi harganya mencapai Rp. 300.000 sampai dengan Rp. 450.000 per kg. Apabila dijadikan kopi bubuk harga jualnya bisa mencapai Rp. 900.000 sampai dengan Rp. 1.000 .000 per kg. Setelah produk dibuat kopi luwak saset dan dikemas dengan baik harga jual semakin meningkat. Untuk kemasan tabung harga jual bisa mencapai Rp. 50.000 per botol dan kemasan kotak Rp. 60.000 per kotak. Sedangkan kemasan saset bisa dijual Rp. 10.000 per saset dengan berat sebanyak 40 gr per saset.

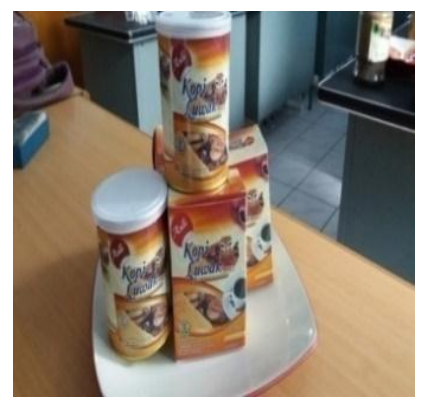

Tabung :

HPP

Rp. 38.000

Harga jual

Rp. 50.000

Margin

Rp. 12.000

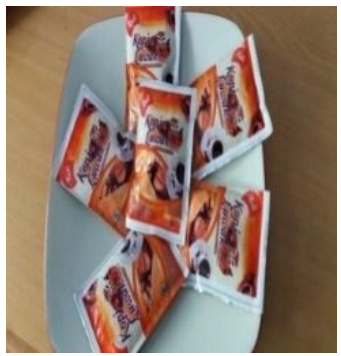

Saset

HPP

Rp. 6.000

Harga jual Rp.

10.000

Margin

Rp. 4.000

Kotak :

HPP

Rp. 42.000

Harga jual

Rp. 60.000

Margin

Rp. 18.000

\section{Pemberdayaan Ekonomi Perempuan Melalui Pelatihan Kewirausahaan}

Pelatihan kewirausahaan ditujukan untuk meningkatkan minat, kemauan, dan motivasi berusaha bagi ibu-ibu dan remaja putri Kecamatan Lebong Tengah. Pada saat ini 
kesempatan kerja baik pada bidang pemerintahan maupun swasta sangat terbatas sehingga berdampak pada semakin meningkatnya jumlah pengangguran, tidak hanya dikota tapi sampai ke desa-desa, apalagi di pedesaan permintaan untuk tenaga kerja untuk pertanian sifatnya juga musiman. Semakin kompleksnya kebutuhan hidup yang tidak terlepas dari kemajuan iptek juga mendorong manusia untuk bisa memiliki barang dan jasa yang semakin variatif. Untuk pemenuhan kebutuhan ini, saat ini tidak bisa hanya diandalkan dari penghasilan kepala keluarga tetapi para ibu rumah tangga juga dituntut untuk bisa berkontribusi dalam membantu suami dalam memenuhi kebutuhan tersebut.

Salah satu alternatif untuk meningkatkan peranan perempuan dalam meningkatkan kesejahteraan keluarga adalah dengan melakukan usaha sendiri atau berwirausaha. Kegiatan ini diharapkan dapat meningkatkan status perempuan dan mempertahankan kelangsungan hidup dalam keluarga. Inti dari pelatihan kewirausahaan adalah melatih kemampuan ibu-ibu dan remaja putri untuk menciptakan sesuatu yang baru dan berbeda melalui berfikir kreatif dan inovatif dengan memanfaatkan potensi dan sumberdaya yang ada, baik yang dihasilkan dari kegiatan usahatani sendiri maupun yang tersedia disekitar mereka. Masyarakat pedesaan sering menafsirkan bahwa kegiatan kewirausahaan bisa dilakukan setelah memiliki asset baru menjalankan usaha, padahal sikap kreatifitas dan inovatif yang mereka miliki merupakan modal dasar untuk mencari peluang menuju sukses dalam berwirausaha.

Dalam kegiatan kewirausahaan ini ibu-ibu dan remaja putri didorong untuk memiliki jiwa dan sikap kewirausahaan, yaitu memiliki rasa percaya diri yang kuat, memiliki komitmen yang tinggi untuk berusaha dan berhasil, memiliki inisiatif, berani mengambil resiko, dan penuh perhitungan dalam menjalankan usaha. Target dari pelatihan kewirausahaan ini adalah ibu-ibu dan remaja putri dapat meningkatkan nilai tambah produk-produk yang ada disekitar mereka melalui pelatihan pembuatan produk, pelatihan pengemasan yang baik, pelatihan analisis usaha, dan pelatihan teknik pemasaran sehingga menumbuhkan kegiatan ekonomi produktif bagi perempuan, khususnya ibu-ibu dan remaja putrid di Kecamatan Lebong Tengah.

\section{Pelatihan Pembuatan Aneka Kue}

Bagi ibu PKK dan remaja Putri yang memiliki keterampilan dalam memasak, maka peluang usaha makanan bisa menjadi pilihan yang baik. Kue merupakan makanan yang disukai semua orang dari berbagai kalangan dari anak-anak hingga orang dewasa dan lanjut usia. Rasanya yang manis dan nikmat membuat semua orang ketagihan dengan rasa bolu. permintaan pasar terhadap bolu semakin meningkat pada momen-momen tertentu seperti pada hari raya idul fithri atau lebaran. Pengalaman dari ketua PKK, yaitu Ani pada saat lebaran omset penjualannya sampai Rp. 200.000 per hari dan hari-hari biasa Rp. 50.000 - Rp. 100.000 per hari. Dan pada saat acara pesta pernikahan mereka juga sering menerima upah dari jasa memasak kue dan dari sewa alat. 

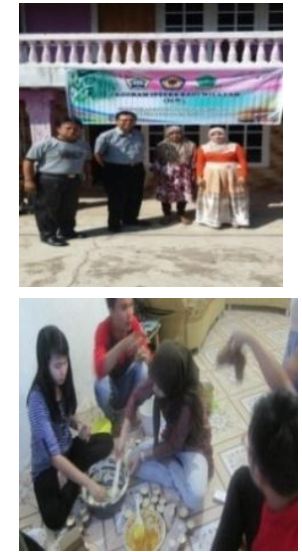
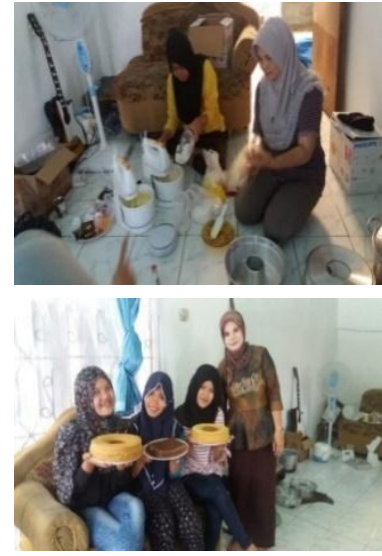
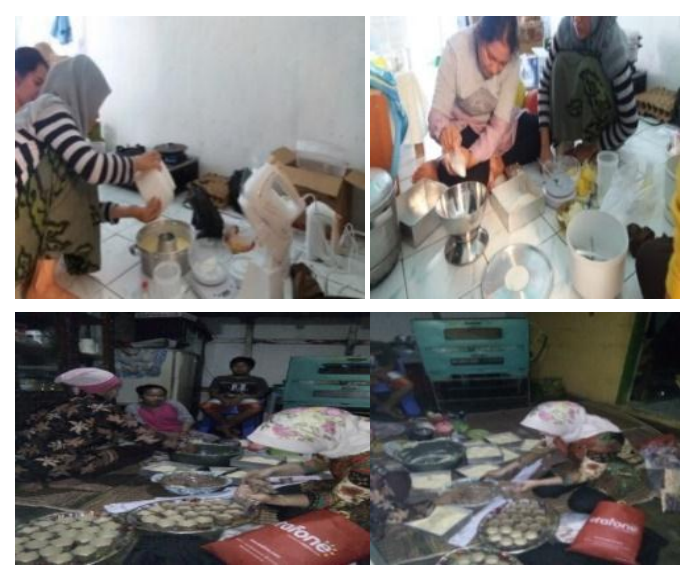

Produk-produk yang dihasilkan
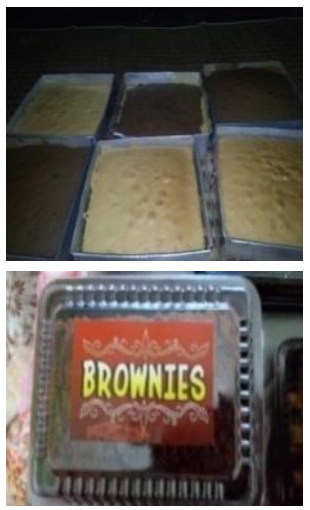
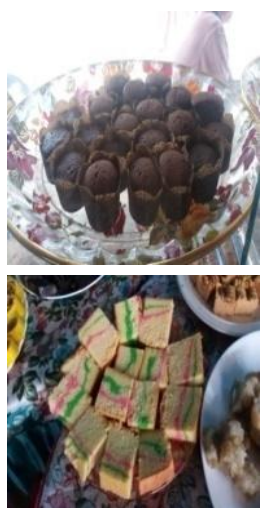
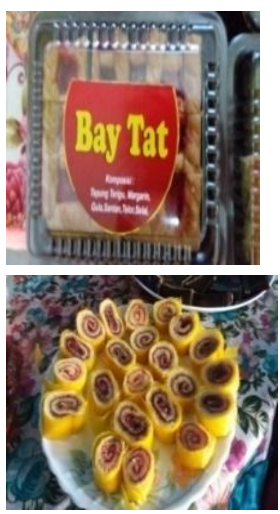
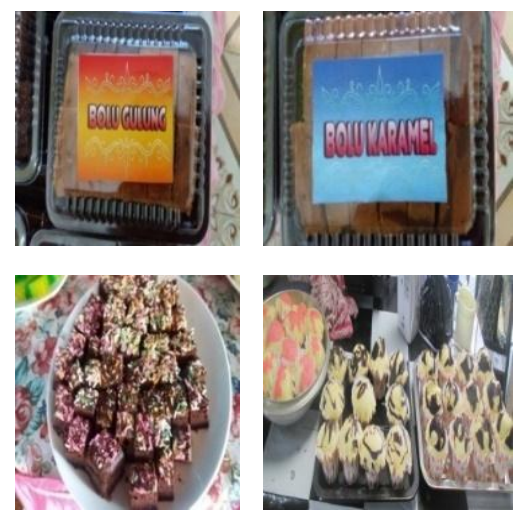

\section{Pelatihan Pembuatan Aneka Keripik}

Keripik adalah jenis makanan ringan yang diolah melalui teknologi yang sangat sederhana dan mudah dengan cara menyusutkan atau mengurangi kadar air yang dikandung oleh bahan baku melalui proses penggorengan hingga dihasilkanlah tekstur yang garing dan renyah. Tujuan dari proses ini adalah agar bahan baku keripik tersebut dapat tahan lebih lama dan tentu saja meningkatkan nilai tambah produk tersebut jika dijual. Keripik merupakan makanan yang sangat digemari oleh semua orang. Mulai dari anak-anak, remaja, muda, dewasa sampai orang tua. Jenis-jenis keripik yang dibuat adalah seperti rempeyek, keripik pisang, keripik singkong, keripik talas.
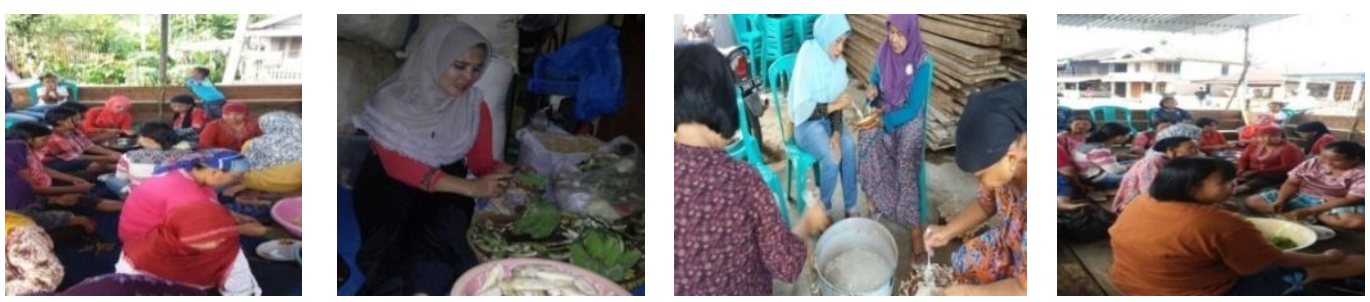

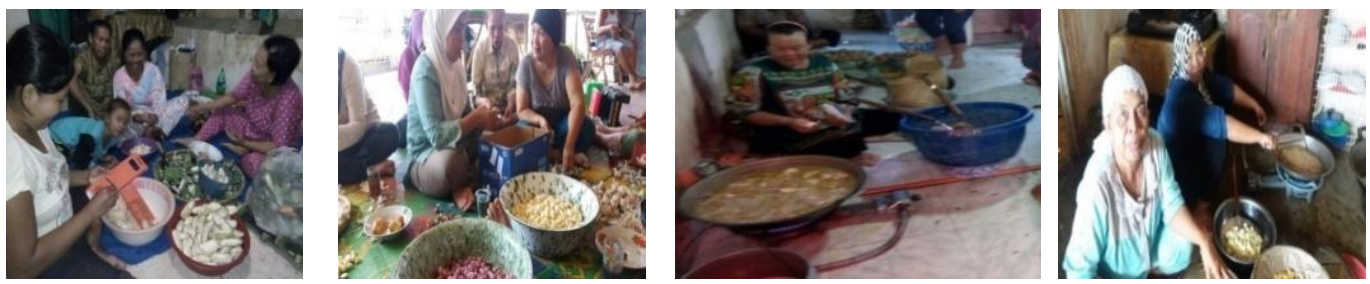

Aneka Keripik yang dihasilkan

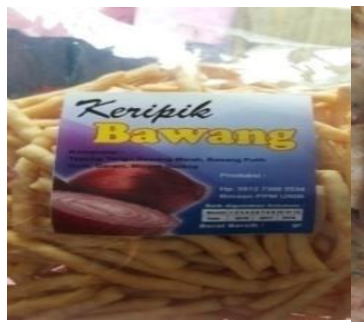

Harga

Pokok Produksi

Rp. 8.000

per bungkus

Harga jual

Rp. 12.000

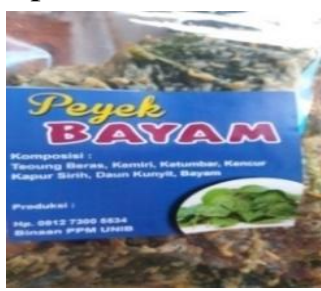

Harga

Pokok Produksi

Rp. 7.000

per bungkus

Harga jual

Rp. 12.000

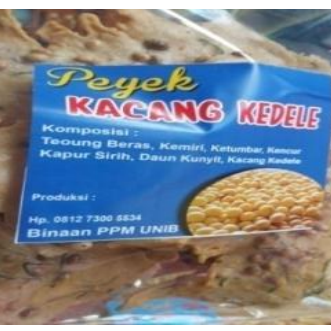

Harga

Pokok Produksi

Rp. 7.500

per bungkus

Harga jual

Rp. 12.000

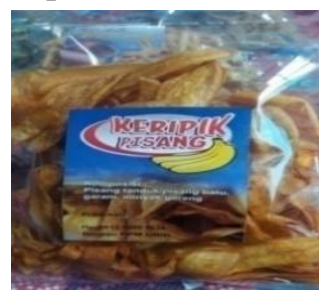

Harga

Pokok Produksi

Rp. 7.500

per bungkus

Harga jual

Rp. 12.000

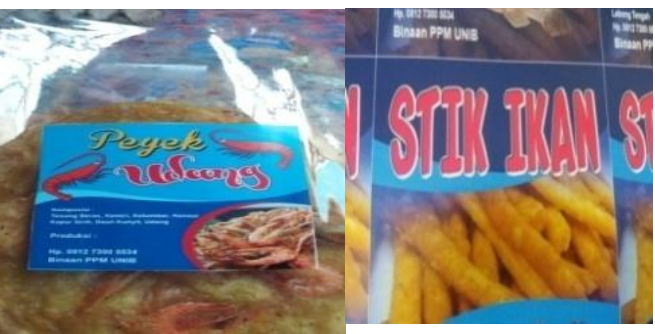

Harga

Harga

Pokok Produksi Pokok Produksi

Rp. 8.000

Rp. 7.000

per bungkus

Harga jual

per bungkus

Harga jual

Rp. 12.000

Rp. 12.000

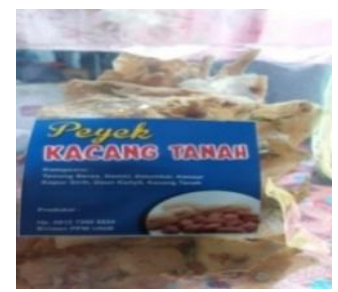

Harga

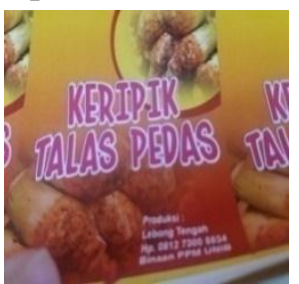

Harga

Pokok Produksi

Pokok Produksi

Rp. 7.000

Rp. 7.000

per bungkus

per bungkus

Harga jual

Harga jual

Rp. 12.000

Rp. 12.000

\section{Pemasaran dan Promosikan Produk}

Promosi dilakukan untuk memperkenalkan barang kepada masyarakat dan untuk meningkatkan penjualan. Sasaran dari promosi adalah seluruh masyarakat konsumen agar mereka mau membeli produk, para pemakai produk pada waktu sekarang, dan masyarakat yang mempunyai daya beli. Dari kegiatan promosi ini diharapkan dapat meningkatnya omset penjulan produk, produk menjadi lebih terkenal, meningkat produksi, dan meningkatnya keuntungan. Untuk memasarkan produk-produk yang dibuat oleh kelompok 
binaan Tim menyewa sebuah warung yang dilengkapi dengan penyediaan etalase dan mengikuti pameran-pameran.

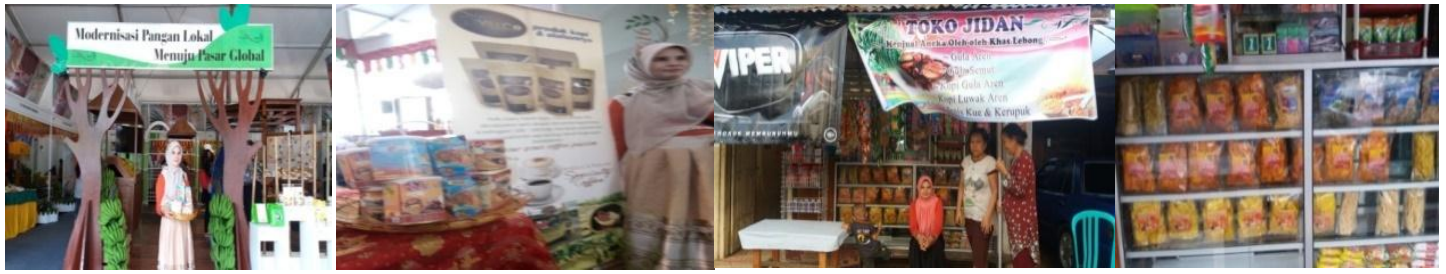

\section{Demplot Pemanfaatan Perkarangan Rumah untuk Tanaman Pangan, Perikanan, dan Ternak}

Di Desa Karang Anyar Kecamatan Lebong Tengah masih banyak perkarangan yang tidak dimanfaatkan. Perkarangan masih banyak yang kosong bahkan dibiarkan menjadi semak-semak. Luas perkarangan cukup luas rata-rata $10 \mathrm{~m}^{2}$ tiap rumah, padahal pekarangan jika dikelola secara intensif, disamping dapat memenuhi kebutuhan konsumsi rumah tangga, juga dapat memberikan sumbangan pendapatan bagi keluarga. Sebagai upaya pemberdayaan masyarakat untuk memanfaatkan sumber daya yang tersedia dilingkungannya, khususnya perkarangan rumah masyarakat diberi percontohan atau demplot pemanfaatan perkarangan dengan berbagai jenis tanaman dan ternak. Percontohan atau kegiatan demplot yang dilakuan adalah demplot tanaman papaya California, tanaman pisang, tanaman cabe, tanaman seledri, sayur, ternak ayam, dan ikan lele dan ikan nila. Luasan perkarangan yang dimanfaatkan berukuran 10 x 20 meter. Selama kegiatan demplot masyarakat diberikan pemahaman bahwa perkarangan rumah tangga memiliki fungsi multiguna yang bisa dimanfaatkan untuk menanami berbagai tanaman, usaha ternak maupun budidaya ikan yang dapat dipanen untuk memenuhi kebutuhan sehari-hari. Pemanfaatan lahan perkarangan merupakan usaha upaya menciptakan kenganekaragaman konsumsi pangan keluarga. Pemanfaatan perkarangan dengan menanam berbagai jenis tanaman pangan membuat akses rumah tangga terhadap kebutuhan bahan pangan menjadi lebih dekat (Astuti et al, 2013).
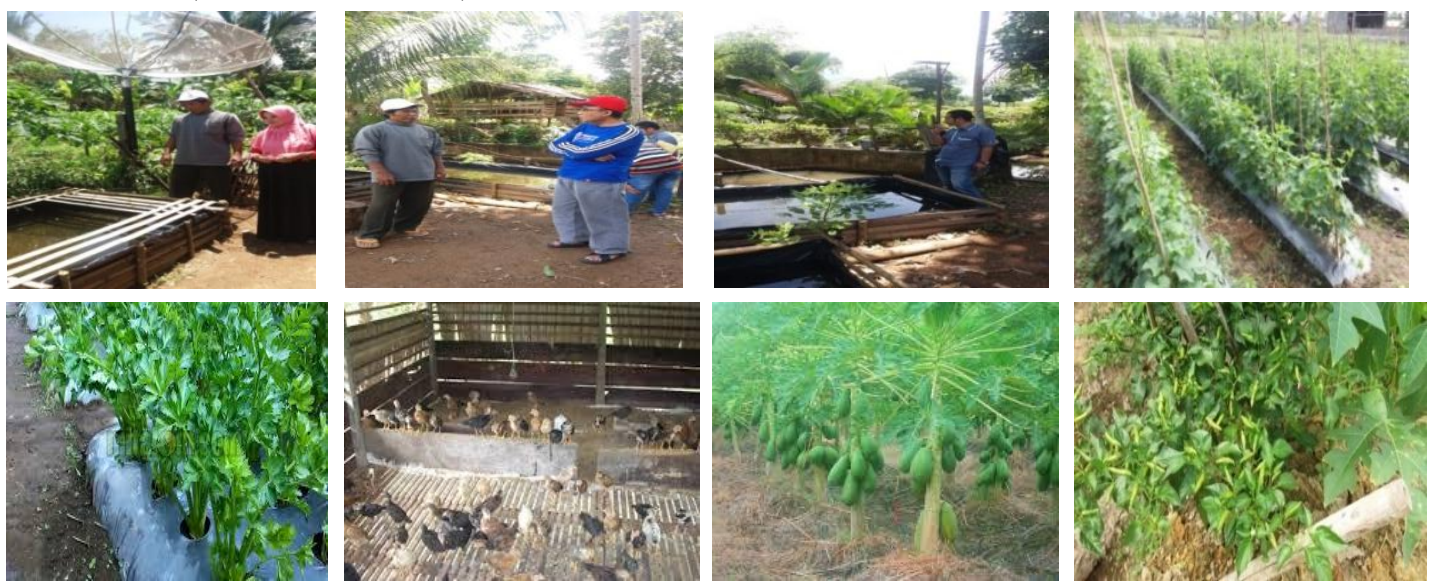


\section{Penyuluhan Kesehatan Lingkungan dan Penyediaan Air Bersih}

Air merupakan kebutuhan utama dalam kehidupan sehari-hari. Disamping memiliki peranan yang penting bagi kehidupan, air juga memberikan dampak yang tidak baik bagi tubuh karena air bisa berperan dalam menularkan penyakit-penyakit saluran pencernaan apabila tidak dikelola dengan baik. Pada saat ini masyarakat lebih menyukai air dalam kemasan yang disedia oleh depot air minum, baik di kota maupun di pedesaan karena alasan lebih praktis dan lebih murah karena bisa langsung diminum. Air dalam kemasan adalah air baku yang telah diproses, dikemas, dan aman diminum yang terdiri dari air mineral dan demineral (air murni). Air mineral adalah air dalam kemasan yang mengandung mineral dalam jumlah tertentu tanpa menambahkan mineral. Sedangkan air demineral atau non mineral atau air murni merupakan air dalam kemasan yang diperoleh melalui proses pemurnian seperti destilasi, deionisasi, reverse osmosis. Yang banyak didistribusikan oleh depot air minum sekarang ini adalah air non mineral atau air muni, padahal tubuh manusia memerlukan mineral-mineral seperti kalsium, natrium, besi, fosfor, dan sebagainya yang juga terkandung dalam air. Selama ini masyarakat tidak mengetahui hal-hal seperti yang ini. Jika dalam minuman atau makanan dikonsumsi mengandung mieral yang sedikit atau bahkan tidak ada, maka akan berdampak tidak baik bagi kesehatan tubuh. Dalam kegiatan ini masyarakat disarankan beberapa bentuk usaha preventif dari dampak negative air minum dalam kemasan bagi kesehatan. Masyarakat sebaiknya mengurangi mengkonsumsi air yang tidak ada mineralnya dan kembali memanfaatkan sumur-sumur mereka sebagai penyedia air bersih untuk kebutuhan sehari-hari.
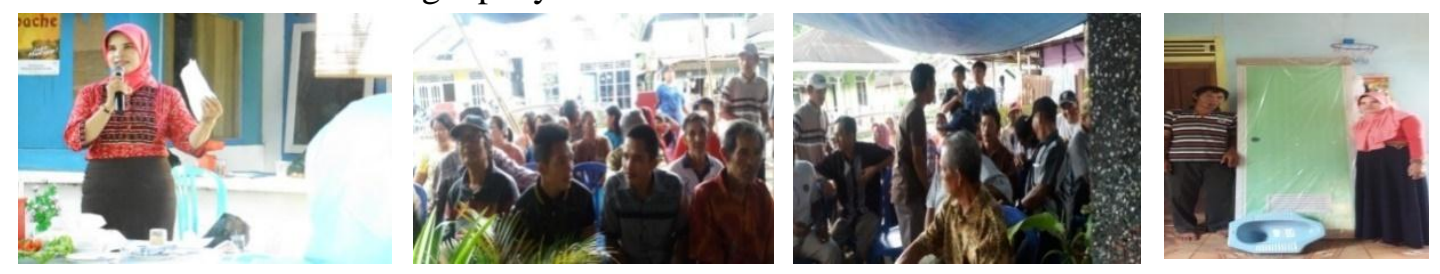

\section{Pelatihan Pembuatan Pakan Ikan bagi Kelompok Tani}

Budidaya ikan mempunyai andil dalam peningkatan pendapatan petani di Kecamatan Lebong Tengah. Jenis ikan yang banyak diusahakan oleh petani adalah ikan nila dan ikan mas, namun ikan nila yang paling dominan. Ikan nila lebih dipilih untuk dipelihara karena ikan nila memiliki keunggulan dari beberapa ikan air tawar lainnya, diantaranya ikan nila memiliki daya tumbuh yang lebih cepat, waktu pembesaran ikan nila tidak lama (2-3 bulan) dan dapat dihasilkan secara berkesinambungan, mudah untuk dikembangbiakkan, mudah dalam pemeliharaannya, dan ikan nila mudah beradaptasi pada perubahan kondisi lingkungan (Prahasta, 2009). Permasalahan yang dihadapi mitra dalam pembuatan pakan untuk usaha pembesaran ikan nila adalah masih terbatasnya pengetahuan dan keterampilan petani mengolah bahan-bahan pembuat pakan tersebut menjadi pakan yang berkualitas dan dapat disimpan lebih lama seperti pellet yang tersedia dipasaran, sehingga ketersediaan pakan selama budidaya tersedia secara kontinu dalam kuantitas dan 
kualitas yang diiinginkan. Untuk mengatasi keterbatasan pengetahuan dan keterampilan petani dalam pembuatan pakan dilakukan penyuluhan dan pelatihan tentang cara menyusun formula pakan yang tepat dan cara pembuatannya dengan memanfaatkan bahan baku lokal yang relative murah dan banyak tersedia disekitar petani.

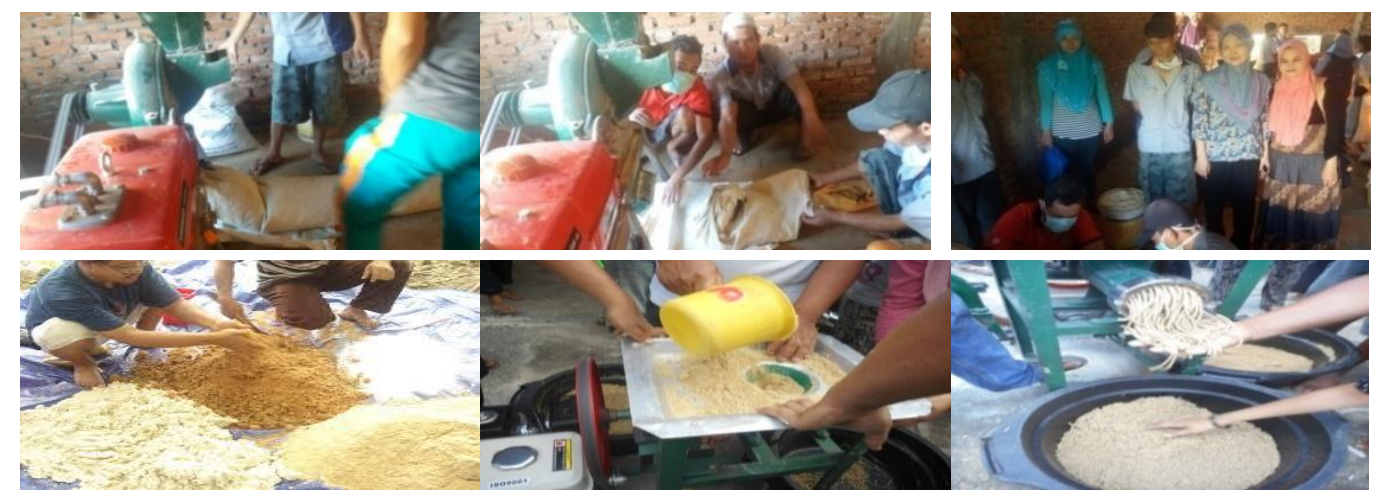

\section{KESIMPULAN DAN SARAN}

\section{Kesimpulan}

Kegiatan pengabdian pada masyarakat ibw "Diversifikasi Produk Aren Dalam Rangka Peningkatan Nilai Tambah Gula Aren Sebagai Produk Unggulan Daerah Kabupaten Lebong" mendapatkan respon yang positif dari para pengrajin aren dan pemerintah Kabupaten Lebong. Hasil kegiatan IbW tahun ketiga (2016) adalah: 1) Pengadaan peralatan penunjang pembuatan gula semut dan kegiatan kewirausahaan, 2) Peningkatan produksi gula semut, 3) Pelatihan pembuatan kopi bubuk, 4) Pelatihan pembuatan kopi luwak aren, 5) Pelatihan Pembuatan kopi jahe, 6) Pembuatan Kopi Gula aren lanjutan, 7) Peningkatan Ekonomi perempuan melalui pelatihan kewirausahaan, 8) Promosi produk melalui penjualan langsung dan pameran, 9) Pemanfaatan perkarangan rumah untuk tanaman perkarangan, perikanan darat, dan ternak secara terintegrasi, 10) Penyuluhan kesehatan lingkungan dan ketersediaan air bersih, 11) Pelatihan pembuatan pakan ikan bagi kelompok tani, 12) Pemberian bantuan sarana MCK.

\section{Saran}

Hasil kegiatan IbW ini mendapatkan apresiasi yang baik dari masyarakat dan pemerintah Kabupaten Lebong dan disarankan untuk dilanjutkan.

\section{DAFTAR PUSTAKA}

Anonym, 2011, Lebong dalam Angka, BPS, Kabupaten Lebong.

Anonym, 2011, Laporan Pertanggung Jawaban Bupati Kabupaten Lebong. 
Anonym, 2012, Rencana Pembangunan Jangka Menengah Daerah (RPJMD) Kabupaten Lebong, Pemda Kabupaten Lebong, Bapeda.

Irawan, 2007, Pengawetan Ikan dan Hasil Perikanan, CV. Aneka, Solo.

Reswita, 2015, Diversifikasi Produk Aren dalam Rangka Peningkatan Nilai Tambah sebagai Produk Unggulan Daerah Kabupaten Lebong, Jurnal Dharma Rafflesia, Volume XIII Tahun 2015.

Reswita, 2016, Pendapatan dan Nilai Tambah Usaha Kopi Bubuk, Jurnal Agrisep, Volume 15 No.1, Maret 2016. 